Volume 4, Issue 1, 2016

\title{
COMBINED MULTI-CRITERIA DECISION MAKING APPROACH BASED ON MACBETH AND MULTI-MOORA METHODS
}

\author{
Nilsen KUNDAKCI* \\ Pamukkale University, Department of Business Administration, Denizli, Turkey \\ Received: 18 February 2016 \\ Accepted: 22 April 2016
}

\begin{abstract}
Various Multi-Criteria Decision Making (MCDM) methods have been developed to support decision making process. The main aim of all MCDM methods is to obtain ranking of the alternatives and select the best one under conflicting criteria. In this paper, a combined MCDM approach is proposed based on MACBETH (Measuring Attractiveness by a Categorical Based Evaluation TecHnique) and MULTIMOORA (Multi Objective Optimization on the basis of Ratio Analysis) methods. In this combined approach, the weights of the criteria are determined with MACBETH method and then MULTI-MOORA method is used to obtain the final ranking of the alternatives. At the end of the paper, to illustrate the applicability of the proposed approach an application of the automobile selection of a marble company is also given.
\end{abstract}

Keywords: MCDM, MACBETH, MULTI-MOORA, Automobile selection

\section{MACBETH VE MULTI-MOORA YÖNTEMLERİNE DAYALI BİRLEȘIK ÇOK KRITTERLİ KARAR VERME YAKLAȘIMI}

\section{Özet}

Karar verme sürecini desteklemek için çeşitli Çok Kriterli Karar Verme (ÇKKV) yöntemleri geliştirilmiştir. ÇKKV yöntemlerinin temel amacı, alternatiflerin çelişen kriterler altında sıralamalarını elde etmek ve içlerinden en iyisini seçmektir. Bu çalışmada, MACBETH ve MULTI-MOORA yöntemlerine dayalı birleşik bir ÇKKV yaklaşımı önerilmiştir. Bu birleşik yaklaşımda, kriterlerin ağırlıkları MACBETH yöntemi ile belirlenirken, alternatiflerin sıralamasının elde edilmesinde MULTI-MOORA yöntemi kullanılmıştır. Çalışmanın sonunda önerilen yaklaşımın uygulanabilirliğini göstermek için bir mermer işletmesinin otomobil seçim uygulamasına yer verilmiştir.

Anahtar Kelimeler : ÇKKV, MACBETH, MULTI-MOORA, Otomobil seçimi

\section{INTRODUCTION}

Whether in the daily lives of people or professional life of businesses, there are typically multiple conflicting criteria and a lot of alternatives that need to be evaluated in the decision making process. To aid this decision process, different MCDM methods are developed in the literature. The objective of this paper is to propose a combined MCDM approach based on MACBETH and MULTI-MOORA methods for the first time. And this proposed approach is applied to an automobile selection problem of a marble company in Denizli, Turkey.

There are studies in the literature that consider automobile selection with MCDM methods. For instance, Güngör and İşler [1] solved automobile selection problem with AHP method. Terzi et al. [2] proposed a decision making model based on AHP and goal programing for automobile selection. Soba [3] applied PROMETHEE method for selecting the best automobile by considering price, fuel, maximum speed, horse power and performance criteria. Sakthivel et al. [4] proposed hybrid MCDM technique for the selection of the best car by integrating 
Fuzzy Analytical Hierarchy Process (FAHP) with Preference Ranking Organization Method for Enrichment Evaluation (PROMETHEE) method. Yavaş et al. [5], examined the customers' car selection criteria and used AHP \& ANP methods to rank these criteria. The main difference of this paper from other studies that consider automobile selection problem is to use a combined approach based on MACBETH and MULTI-MOORA methods for the first time.

This paper is organized as follows: In the second section MACBETH method is explained and then MULTI-MOORA method is introduced in the third section. In the fourth section, application of the combined approach in a marble company is given. Finally, results of the application are discussed and suggestions for future research are given in the fifth section.

\section{MACBETH Method}

MACBETH (Measuring Attractiveness by a Categorical Based Evaluation TecHnique) was firstly proposed by Bana e Costa, Vansnick and De Corte in 1990s. It was applied to different fields after introduced in the $\mathrm{XI}^{\text {th }}$ International Conference on MCDM [6]. MACBETH is a MCDM method that helps to build a quantitative model of values and it avoids forcing decision makers to produce direct numerical representations of their preferences [7]. It helps the decision makers to rank the alternatives based on aggregated measurement of relative weighted attractiveness of alternatives with respect to several decision criteria [8].

In the literature there are various studies that apply MACBETH method to different fields. For instance it is used to solve complex strategic problems of Santa Catarina textile industry [9], for conflict dissolution in the construction of a new railway [10], to analyze spatial conflicts in the investment policy of new inter-municipal road-links [11], to assign priorities for maintenance, repair and refurbishment in managing a municipal housing stock [12], for strategic town planning [13], to help credit granting decisions in banking sector [14], for bid evaluation processes in public call for tenders [15], to solve career choice problem [7], for a certain model of coalition formation to determine stable governments [16], for multi-criteria industrial performance expressions [17], for the evaluation and comparison of the technical performance of three hydrogen storage technologies [18], to measure the satisfaction degree of services orchestration to the quality attributes requirements [19], to solve real time supplier selection problems [20], to build a multidimensional value-based population health indices [21], to solve facility layout selection problems [8].

While applying MACBETH method the relevant steps adapted as presented below:

Step 1. Firstly decision criteria are defined and then value tree is formed.
Step 2. After forming the value tree, alternatives are determined. Then the ordinal performance levels representing the possible performance of the alternatives with respect to a particular criterion are defined. Minimum two reference levels are required to be identified as upper reference (good) level and lower reference (neutral) level. On MACBETH scale, the upper reference level has a score of 100 , while the lower reference level has a score of 0 . Here, 100 does not necessarily represent the best possible score and 0 does not denote the worst performance of an alternative for a given criterion [20].

Step 3. An $m \times m$ matrix is formed for the alternatives where $m$ indicates the number of alternatives for that criterion. In this matrix, alternatives are arranged from left to right according to their importance. This is made to quantify the qualitative performance levels and convert quantitative performance levels into MACBETH scale. Also the same procedure is applied for the criteria.

Step 4. Pairwise comparisons are made for the criteria and alternatives based on difference of attractiveness. MACBETH method helps to map the difference of attractiveness using a set of semantic scale having seven categories arranged in descending order of their importance. The equivalent numerical scales and significances of these semantic scales can be seen in Table $1[20,7]$.

Table 1. Semantic scale of MACBETH

\begin{tabular}{lcl}
\hline \multicolumn{1}{c}{$\begin{array}{c}\text { Semantic } \\
\text { Scale }\end{array}$} & $\begin{array}{c}\text { Equivalent } \\
\text { Numerical } \\
\text { Scale }\end{array}$ & \multicolumn{1}{c}{ Significance } \\
\hline Null & 0 & $\begin{array}{l}\text { Indifference between } \\
\text { alternatives } \\
\text { An alternative is very } \\
\text { weakly attractive over } \\
\text { another }\end{array}$ \\
Very Weak & 1 & $\begin{array}{l}\text { An alternative is weakly } \\
\text { attractive over another }\end{array}$ \\
Moderate & 2 & $\begin{array}{l}\text { An alternative is } \\
\text { moderately attractive over } \\
\text { another }\end{array}$ \\
Strong & 3 & $\begin{array}{l}\text { An alternative is strongly } \\
\text { attractive over another }\end{array}$ \\
& 4 & $\begin{array}{l}\text { An alternative is very } \\
\text { strongly attractive over } \\
\text { another }\end{array}$ \\
Very Strong & & $\begin{array}{l}\text { An alternative is } \\
\text { extremely attractive over } \\
\text { another }\end{array}$ \\
\hline & 5 &
\end{tabular}

Step 5. The judgments provided by the decision maker are checked for consistency. If the provided judgments are found to be inconsistent, M-MACBETH software suggests possible alterations to make the judgments consistent [12]. 
Step 6. The consistent judgments are transformed into a suitable numerical scale, identified as the MACBETH scale based on linear programming models.

Step 7. Finally, the weighted global scores representing the overall attractiveness of the considered alternatives are computed using an additive aggregation model to rank the alternatives.

For obtaining MACBETH scores of qualitative performance levels, the following procedure is used $[8,19$, 20]:

Firstly, decision maker is asked to compare the pairs of alternatives under each criterion. If the decision maker prefers alternative $A_{i}$ to $A_{i^{\prime}}$ for a criterion $j$, this is showed as:

$$
A_{i}>A_{i^{\prime}}
$$

Secondly, the decision maker expresses his/her strengths of preference about the alternatives. These strengths of preference are characterized with semantic scale in Table 1. If the decision maker cannot give his/her strengths of preference but only his/her preferences, this is noted by $P$. The decision maker prefers the alternative $A_{i}$ to $A_{i^{\prime}}$ with a strength $h \in\{0,1,2,3,4,5,6\}$ for a criterion $j$,

$$
A_{i} \succ^{h} A_{i^{\prime}}
$$

This is equivalent to:

$$
A_{i}-A_{i^{\prime}}=h \alpha
$$

where $\alpha$ is a coefficient necessary to meet condition $A_{i}$ and $A_{i^{\prime}} \in[0,100]$

Consider an example with four alternatives and their preference of importance for the $j^{\text {th }}$ criterion are as $\mathrm{A}_{2}>$ $\mathrm{A}_{4}>\mathrm{A}_{1}>\mathrm{A}_{3}$. If $v_{j}\left(\mathrm{~A}_{2}\right), v_{j}\left(\mathrm{~A}_{4}\right), v_{j}\left(\mathrm{~A}_{1}\right)$ and $v_{j}\left(\mathrm{~A}_{3}\right)$ are MACBETH scores for $\mathrm{A}_{2}, \mathrm{~A}_{4}, \mathrm{~A}_{1}, \mathrm{~A}_{3}$ respectively, then $v_{j}\left(\mathrm{~A}_{2}\right)=100, v_{j}\left(\mathrm{~A}_{3}\right)=0$ and $v_{j}\left(\mathrm{~A}_{2}\right)>v_{j}\left(\mathrm{~A}_{4}\right)>v_{j}\left(\mathrm{~A}_{1}\right)>v_{j}\left(\mathrm{~A}_{3}\right)$. Then, decision maker expresses his/her strengths of preferences for alternatives using semantic scale in Table 1. These preference strengths of alternatives for $j^{\text {th }}$ criterion are given in Table 2.

Table 2. Preference strengths of alternatives for $j^{\text {th }}$ criterion

\begin{tabular}{l|llll}
\hline Alternatives & $\mathbf{A}_{2}$ & $\mathbf{A}_{4}$ & $\mathbf{A}_{1}$ & $\mathbf{A}_{3}$ \\
\hline $\mathbf{A}_{2}$ (good) & No & Strong & $P$ & $P$ \\
$\mathbf{A}_{4}$ & & No & Very Weak & $P$ \\
$\mathbf{A}_{1}$ & & & No & Moderate \\
$\mathbf{A}_{3}$ (neutral) & & & & No \\
\hline
\end{tabular}

From the data in Table 2, these equation systems can be obtained;

$$
\begin{aligned}
& v_{j}\left(A_{2}\right)-v_{j}\left(A_{4}\right)=4 \alpha \\
& v_{j}\left(A_{4}\right)-v_{j}\left(A_{1}\right)=\alpha \\
& v_{j}\left(A_{1}\right)-v_{j}\left(A_{3}\right)=3 \alpha
\end{aligned}
$$

Here, $v_{j}\left(\mathrm{~A}_{2}\right)=100\left(\right.$ good) and $v_{j}\left(\mathrm{~A}_{3}\right)=0$ (neutral). After solving equations (4) - (6), solutions are obtained as; $\alpha=12.5, v_{j}\left(\mathrm{~A}_{4}\right)=50$ and $v_{j}\left(\mathrm{~A}_{1}\right)=37.5$.

By adopting the same procedure, the quantification of alternatives for all the remaining criteria and the criteria weights can be obtained. Then, the converted MACBETH scores for all the performance measures are multiplied by the respective criteria weights and are added together to find out the overall attractiveness scores for the alternatives. The final overall score is obtained using the following additive value model $[8,14]$ :

$$
\begin{aligned}
& V\left(A_{i}\right)=\sum_{j=1}^{n} w_{j}\left(v_{j}\left(A_{i}\right)\right) \\
& \sum_{j=1}^{n} w_{j}=1, \quad w_{j}>0 \text { and }\left\{\begin{array}{l}
v_{j}\left(A_{i}^{\text {good }}\right)=100 \\
v_{j}\left(A_{i}^{\text {neutral }}\right)=0
\end{array}\right.
\end{aligned}
$$

where $w_{j}$ indicates weight of the $j^{\text {th }}$ criterion. The final ranking of the alternatives is determined based on the $V\left(A_{i}\right)$ values. MACBETH method is supported by MMACBETH software (http://www.mmacbeth.com/en/ downloads.html) developed using algorithm based on linear programming models [20]. In this paper, the weights of the criteria are determined by using M-MACBETH software.

\section{MOORA Method}

MOORA (Multi Objective and Optimization on the basis of Ratio Analysis) method was firstly proposed by Brauers and Zavadskas in 2006 [22]. Although MOORA is a relatively new method it has been applied to different areas in the literature. For example, MOORA method is used for privatization in a transition economy [22], determining the ranking of contractor firms [23], road design [24], evaluation of inner climate [25], regional development studies [26, 27], project management [28], parametric optimization of milling process [29], the selection of optimal network [30], determining the critical path in project management [31], determining the popularity of touristic places [32], supply chain strategy selection [33], selecting the best intelligent manufacturing system [34], personnel selection [35, 36], bank branch location selection [37], ranking cloud storage technology firms [38].

MOORA method has three types namely Ratio System, 
Reference Point Approach and Full Multiplicative Form. Lastly, the final ranking of the alternatives can be obtained with MULTI-MOORA based on dominance theory.

\subsection{Ratio System of MOORA}

The steps of Ratio System of MOORA can be summarized as follows [22, 23]:

Step 1. Decision matrix $X$ is formed where $x_{i j}$ indicates the value of $i^{\text {th }}(i=1,2, \ldots, m)$ alternative based on $j^{\text {th }}(j=1,2, \ldots, n)$ criterion

$$
X=\left[\begin{array}{cccc}
x_{11} & x_{12} & \cdots & x_{1 n} \\
x_{21} & x_{22} & \cdots & x_{2 n} \\
\vdots & \vdots & \ddots & \vdots \\
x_{m 1} & x_{m 2} & \cdots & x_{m n}
\end{array}\right]
$$

Step 2. Decision matrix is normalized with Eq. (10)

$$
x_{i j}^{*}=\frac{x_{i j}}{\sqrt{\sum_{j=1}^{n} x_{i j}^{2}}}
$$

Step 3. Weighted normalized decision matrix is formed with the help of Eq. (11). Here $w_{j}$ shows the weight of the $j^{\text {th }}$ criterion.

$$
v_{i j}=w_{j} * x_{i j}^{*}
$$

Step 4. Final preference $\left(y_{i}^{*}\right)$ values obtained by using Eq. (12). Here $j=1,2, \ldots, g$ indicates the criteria to be maximized and $j=g+1, g+2, \ldots, n$ shows the criteria to be minimized.

$$
y_{i}^{*}=\sum_{j=1}^{g} v_{i j}-\sum_{j=g+1}^{n} v_{i j}
$$

Step 5. Ranking of the alternatives are obtained by ranking $y_{i}^{*}$ values in descending order.

\subsection{The Reference Point Approach of MOORA}

In the Reference Point Approach, the first three step will be the same with Ratio System of MOORA. The other steps can be summarized as [23]:

Step 1. Decision matrix $X$ is formed like in Eq. (9)

Step 2. Decision matrix is normalized with Eq. (10)

Step 3. Weighted normalized decision matrix is formed with Eq. (11).

Step 4. Reference points $\left(r_{j}\right)$ are determined for each criterion. While determining reference points, highest values are chosen for maximization criteria, minimum values are chosen for the minimization criteria.
Step 5. The distance between the alternatives and the reference points are calculated and then the best alternative is determined by using the Tchebycheff MinMax metric given in Eq. (13).

$$
\min _{i}\left\{\max _{j}\left(\left|w_{j} r_{j}-v_{i j}\right|\right)\right\}
$$

According to the Eq. (13), firstly maximum distance values of each alternative to the reference points under all criteria are determined and then from these values minimum one is chosen as the best alternative. Final ranking of the alternatives are obtained by ranking the maximum distance values in increasing order.

\subsection{Full Multiplicative Form of MOORA}

The steps of Full Multiplicative Form of MOORA can be given as follows [28]:

Step 1. Decision matrix $X$ is formed like in Eq. (9).

Step 2. Multiplicative ranking index $U_{i}$ for each alternative are determined with Eq. (14).

$$
U_{i}=\frac{A_{i}}{B_{i}}
$$

Here $A_{i}=\prod_{j=1}^{g} x_{i j}^{w_{j}}$, for $i^{\text {th }}$ alternative for the criteria to be maximized $(j=1,2, \ldots, g)$ and $B_{i}=\prod_{j=g+1}^{n} x_{i j}^{w_{j}}$ for $i^{\text {th }}$ alternative for the criteria to be minimized $(j=g+1$, $g+2, \ldots, n)[28,39]$.

Step 3. Ranking of the alternatives are obtained by ranking $U_{i}$ values in descending order.

\subsection{MULTI-MOORA}

MULTI-MOORA method is based on the dominance theory and aims to reach one final ranking from three ranks obtained with Ratio System, Reference Point Approach and Full Multiplicative Form [40].

MULTI-MOORA was firstly proposed by Brauers and Zavadskas in 2010 [28]. And it is used to solve different MCDM problem by various authors. Brauers and Ginevičius [41] tested the economy of the Belgian regions by using MULTI-MOORA. Brauers and Zavadskas [40] proposed MULTI-MOORA to decide on a bank loan for buying property. Brauers et al. [42] used fuzzy MULTIMOORA for ranking the EU Member States according to their performance. Baležentis et al. [43], used fuzzy MULTI-MOORA for personnel selection. Brauers and Zavadskas [44] tested the robustness of MULTI-MOORA. Datta et al. [45] proposed grey MULTI-MOORA to select industrial robot. Baležentis and Baležentis [46], explained 
both crisp and fuzzy MULTI-MOORA and summarized the application areas of MOORA and MULTIMOORA. Aksoy [47] evaluated the performances of companies operated by Turkish Coal Enterprises with AHP-based MULTI-MOORA and COPRAS methods. Obayiuwana and Falowo [39], used MULTI-MOORA for wireless network selection.

\section{APPLICATION}

In this part, the applicability of the combined approach is illustrated. For this reason, a MCDM problem of a marble company located in Denizli, Turkey tried to be solved with this approach. A marble company decided to purchase an automobile for the general manager of the company. So it is aimed to select the most appropriate automobile for the general manager as an official car. After a preliminary research they decided to purchase diesel automobile and determined the possible alternatives as $\mathrm{A}_{1}$ Mercedes C 200d, $\mathrm{A}_{2}$ Audi A4 2.0 TDI, $\mathrm{A}_{3}$ Volkswagen Passat 2.0 TDI, A 4 Volvo S60 2.0 TDI, $\mathrm{A}_{5}$ Opel Insignia 2.0 CDTI, A 6 BMW 320d, $A_{7}$ Ford Mondeo 2.0 TDCI, $\mathrm{A}_{8}$ Toyota Avensis 2.0 D-3D and $\mathrm{A}_{9}$ Peugeot 5082.0 .

There are a lot of automobile alternatives and conflicting criteria to be considered, so automobile selection is an important and difficult decision for the marble company. For selecting the best automobile for the general manager, a combined approach based on MACBETH and MULTI-MOORA methods are proposed. The weights of the decision criteria are determined with MACBETH method and then MULTI-MOORA method is used to determine the ranking of the alternatives.

First of all, decision criteria are defined and expressed in the form of a value tree as seen in Figure 1. These criteria are; $\mathrm{C}_{1}$ Price (TL), $\mathrm{C}_{2}$ Fuel consumption (lt $/ 100 \mathrm{~km}), \mathrm{C}_{3}$ Safety, $\mathrm{C}_{4}$ Brand image, $\mathrm{C}_{5}$ After sales service, $\mathrm{C}_{6}$ Comfort, $\mathrm{C}_{7}$ Design, $\mathrm{C}_{8}$ Engine power (HP) and $\mathrm{C}_{9} \mathrm{CO}_{2}$ Emissions (g/km).

Figure 1. MACBETH value tree

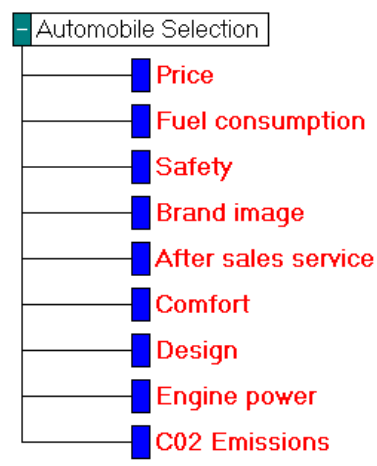

In order to determine the weights of the criteria with MACBETH method, criteria are entered into $\mathrm{M}$ MACBETH software in descending order of their importance from left to right and top to bottom in the weighting matrix, as shown in Table 3.

In order to convert the performance levels for all criteria into proportionate quantitative MACBETH scores, they are pair-wise compared with the help of a seven point semantic scale. M-MACBETH software checked the consistency of these judgments and it is found that the entered judgments are consistent. Further, based on the provided differences of attractiveness, M-MACBETH software converts the ordinal performance levels into proportionate cardinal MACBETH scale using linear programming models. This MACBETH scale can be seen in the last column of the Table 3 and these values indicate the weights of the criteria. The weights of the criteria obtained with the MACBETH method can be seen in Table 4 .

Table 3. Comparison of the criteria

\begin{tabular}{|c|c|c|c|c|c|c|c|c|c|c|c|c|}
\hline \multicolumn{12}{|c|}{ Weighting (Automobile Selection) } & \multirow{3}{*}{$\begin{array}{c}\text { extreme } \\
\text { ч. strong }\end{array}$} \\
\hline 畻 & [C1] & {$[\mathrm{C} 2]$} & [ C3] & [C4] & {$[\mathrm{C} 5]$} & [C6 ] & [ C7 ] & [ C8 ] & [ C9] & [ all lower ] & $\begin{array}{l}\text { Current } \\
\text { scale }\end{array}$ & \\
\hline [C1] & no & very weak & weak & weak & moderate & strong & strong & v. strong & extreme & positive & 20.00 & \\
\hline [ C2 ] & & no & very weak & very weak & weak & moderate & moderate & strong & v. strong & positive & 16.84 & stiong \\
\hline [C3] & & & no & very weak & weak & moderate & moderate & strong & v. strong & positive & 15.79 & weak \\
\hline [ C4 ] & & & & no & very weak & weak & moderate & strong & $v$. strong & positive & 14.74 & veru weak \\
\hline$[\mathrm{C5}]$ & & & & & no & very weak & weak & moderate & strong & positive & 11.58 & no \\
\hline [C6] & & & & & & no & very weak & weak & moderate & positive & 8.42 & \\
\hline [ C7 ] & & & & & & & no & very weak & weak & positive & 7.37 & \\
\hline [C8] & & & & & & & & no & very weak & positive & 4.21 & \\
\hline [ C9] & & & & & & & & & no & positive & 1.05 & \\
\hline [ all lower ] & & & & & & & & & & no & 0.00 & \\
\hline \multicolumn{13}{|c|}{ Consistent judgements } \\
\hline UNR & $\Rightarrow$ & & & \begin{tabular}{|c|c|c|} 
思 & DIFF \\
DIFF & MAC \\
BETH
\end{tabular} & 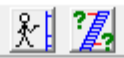 & & & & & & & \\
\hline
\end{tabular}


Table 4. Weights of the criteria

\begin{tabular}{cccccccccc}
\hline Criteria & $\mathrm{C}_{1}$ & $\mathrm{C}_{2}$ & $\mathrm{C}_{3}$ & $\mathrm{C}_{4}$ & $\mathrm{C}_{5}$ & $\mathrm{C}_{6}$ & $\mathrm{C}_{7}$ & $\mathrm{C}_{8}$ & $\mathrm{C}_{9}$ \\
\hline Weights & 0.20 & 0.1684 & 0.1579 & 0.1474 & 0.1158 & 0.0842 & 0.0737 & 0.0421 & 0.0105 \\
\hline
\end{tabular}

After the weights of the criteria are determined by MACBETH method, MULTI-MOORA method is used to find the ranking of the automobile alternatives. According to MULTI-MOORA method, firstly decision matrix is formed as seen in Table 5. In this table, data of the automobile alternatives are given. The data for $\mathrm{C}_{1}, \mathrm{C}_{2}, \mathrm{C}_{3}$, $\mathrm{C}_{8}$ and $\mathrm{C}_{9}$ are quantitative data whereas data for the $\mathrm{C}_{4}, \mathrm{C}_{5}$, $\mathrm{C}_{6}$ and $\mathrm{C}_{7}$ are qualitative data. The quantitative data like $\mathrm{C}_{1}$ Price (TL), $\mathrm{C}_{2}$ Fuel consumption (1t/100km), $\mathrm{C}_{8}$ Engine power (HP) and $\mathrm{C}_{9} \mathrm{CO}_{2}$ Emissions are obtained from the websites of the related automobiles $[48,49,50,51,52,53$, 54,55 , and 56]. The data for $\mathrm{C}_{3}$ that shows the safety values of the automobiles are obtained from Euro NCAP [57]. Euro NCAP has created the safety rating system to help consumers, compare automobiles more easily and to help them identify the safest choice for their needs. The safety rating is determined from a series of vehicle tests, designed and carried out by Euro NCAP. While obtaining the qualitative data, decision maker evaluated the alternatives by using 5 point scale in which $1=$ Poor, $2=$ Fair, 3=Good, 4=Very good, 5=Excellent. On the other hand, some of the automobile selection criteria have to be maximized and the others minimized. As seen in Table 5, $\mathrm{C}_{3}, \mathrm{C}_{4}, \mathrm{C}_{5}, \mathrm{C}_{6}, \mathrm{C}_{7}$ and $\mathrm{C}_{8}$ are maximization criteria and $\mathrm{C}_{1}$, $\mathrm{C}_{2}, \mathrm{C}_{9}$ are minimization criteria. After forming the decision matrix, it is normalized by using Eq. (10) as shown in Table 6.

Table 5. Quantitative data for performance evaluation of alternatives

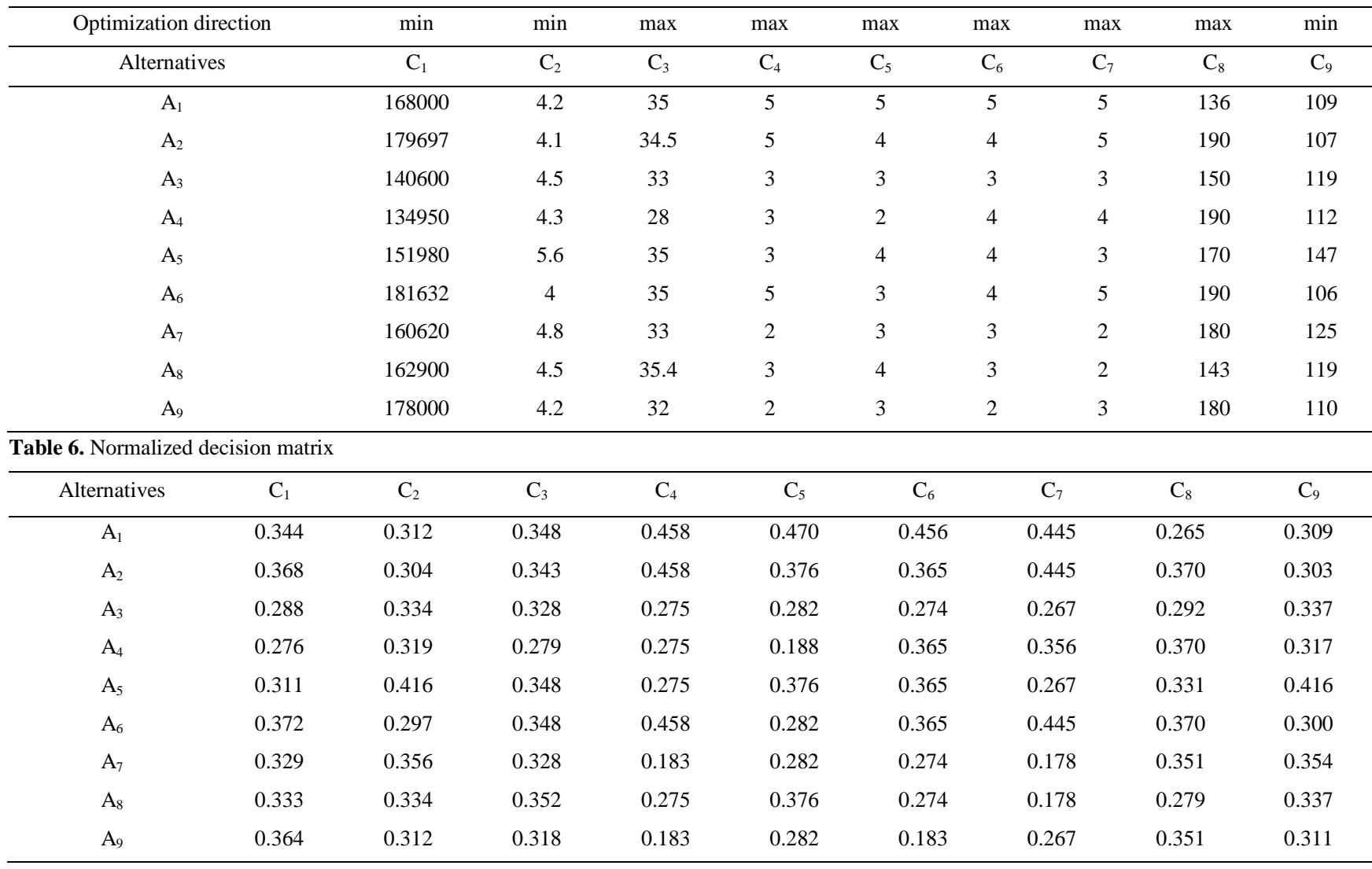

Then, the weighted normalized decision matrix is formed by using Eq. (11) as shown in Table 7. From the weighted normalized decision matrix $y_{i}^{*}$ values of each alternative are calculated with Eq. (12). These values can be seen in the last column of Table 7. And the ranking of alternatives with Ratio System of MOORA by considering $y_{i}^{*}$ values are given in Table 8. 
Table 7. Weighted normalized decision matrix and $y_{i}^{*}$ values

\begin{tabular}{|c|c|c|c|c|c|c|c|c|c|c|}
\hline Alternatives & $\mathrm{C}_{1}$ & $\mathrm{C}_{2}$ & $\mathrm{C}_{3}$ & $\mathrm{C}_{4}$ & $\mathrm{C}_{5}$ & $\mathrm{C}_{6}$ & $\mathrm{C}_{7}$ & $\mathrm{C}_{8}$ & $\mathrm{C}_{9}$ & $y_{i}^{*}$ \\
\hline $\mathrm{A}_{1}$ & 0.069 & 0.053 & 0.055 & 0.068 & 0.054 & 0.038 & 0.033 & 0.011 & 0.003 & 0.135 \\
\hline $\mathrm{A}_{2}$ & 0.074 & 0.051 & 0.054 & 0.068 & 0.044 & 0.031 & 0.033 & 0.016 & 0.003 & 0.116 \\
\hline $\mathrm{A}_{3}$ & 0.058 & 0.056 & 0.052 & 0.041 & 0.033 & 0.023 & 0.020 & 0.012 & 0.004 & 0.063 \\
\hline $\mathrm{A}_{4}$ & 0.055 & 0.054 & 0.044 & 0.041 & 0.022 & 0.031 & 0.026 & 0.016 & 0.003 & 0.067 \\
\hline $\mathrm{A}_{5}$ & 0.062 & 0.070 & 0.055 & 0.041 & 0.044 & 0.031 & 0.020 & 0.014 & 0.004 & 0.067 \\
\hline $\mathrm{A}_{6}$ & 0.074 & 0.050 & 0.055 & 0.068 & 0.033 & 0.031 & 0.033 & 0.016 & 0.003 & 0.107 \\
\hline $\mathrm{A}_{7}$ & 0.066 & 0.060 & 0.052 & 0.027 & 0.033 & 0.023 & 0.013 & 0.015 & 0.004 & 0.033 \\
\hline $\mathrm{A}_{8}$ & 0.067 & 0.056 & 0.056 & 0.041 & 0.044 & 0.023 & 0.013 & 0.012 & 0.004 & 0.061 \\
\hline $\mathrm{A}_{9}$ & 0.073 & 0.053 & 0.050 & 0.027 & 0.033 & 0.015 & 0.020 & 0.015 & 0.003 & 0.031 \\
\hline
\end{tabular}

Table 8. Ranking of alternatives with Ratio System of MOORA

\begin{tabular}{clc}
\hline Alternatives & Brands & $y_{i}^{*}$ \\
\hline $\mathrm{A}_{1}$ & Mercedes C 200d & 0.135 \\
$\mathrm{~A}_{2}$ & Audi A4 2.0 TDI & 0.116 \\
$\mathrm{~A}_{6}$ & BMW 320 d & 0.107 \\
$\mathrm{~A}_{5}$ & Opel Insignia 2.0 CDTI & 0.067 \\
$\mathrm{~A}_{4}$ & Volvo S60 2.0 TDI & 0.067 \\
$\mathrm{~A}_{3}$ & Volkswagen Passat 2.0 TDI & 0.063 \\
$\mathrm{~A}_{8}$ & Toyota Avensis 2.0 D-3D & 0.061 \\
$\mathrm{~A}_{7}$ & Ford Mondeo 2.0 TDCI & 0.033 \\
$\mathrm{~A}_{9}$ & Peugeot 508 2.0 & 0.031 \\
\hline
\end{tabular}

In Reference Point Approach of MOORA, firstly reference points are determined for each criterion from the weighted normalized decision matrix. While determining reference points, highest values are choosen for maximization criteria $\left(\mathrm{C}_{3}, \mathrm{C}_{4}, \mathrm{C}_{5}, \mathrm{C}_{6}, \mathrm{C}_{7}\right.$ and $\left.\mathrm{C}_{8}\right)$ and minimium values are choosen for the minimization criteria $\left(C_{1}, C_{2}, C_{9}\right)$. These points are given at the last row of Table 9. Then, the distances between the alternatives and the reference points are calculated like in Table 9. Later, maximum values of these distances are determined and given in the last column of the Table 9. Then the best alternative is chosen by using the Tchebycheff Min-Max metric seen in Eq. (13). Final ranking of the alternatives are obtained by ranking the maximum distance values in increasing order like in Table 10.

Table 9. Reference Point Approach of MOORA

\begin{tabular}{ccccccccccccccc}
\hline Alternatives & $\mathrm{C}_{1}$ & $\mathrm{C}_{2}$ & $\mathrm{C}_{3}$ & $\mathrm{C}_{4}$ & $\mathrm{C}_{5}$ & $\mathrm{C}_{6}$ & $\mathrm{C}_{7}$ & $\mathrm{C}_{8}$ & $\mathrm{C}_{9}$ & $\mathrm{Max}$ \\
\hline $\mathrm{A}_{1}$ & 0.014 & 0.003 & 0.001 & 0.000 & 0.000 & 0.000 & 0.000 & 0.004 & 0.000 & 0.014 \\
$\mathrm{~A}_{2}$ & 0.018 & 0.001 & 0.001 & 0.000 & 0.011 & 0.008 & 0.000 & 0.000 & 0.000 & 0.018 \\
$\mathrm{~A}_{3}$ & 0.002 & 0.006 & 0.004 & 0.027 & 0.022 & 0.015 & 0.013 & 0.003 & 0.000 & 0.027 & 0.000 & 0.000 & 0.033 \\
$\mathrm{~A}_{4}$ & 0.000 & 0.004 & 0.012 & 0.027 & 0.033 & 0.008 & 0.007 & 0.000 & 0.001 & 0.027 \\
$\mathrm{~A}_{5}$ & 0.007 & 0.020 & 0.001 & 0.027 & 0.011 & 0.008 & 0.013 & 0.002 & 0.0013 \\
$\mathrm{~A}_{6}$ & 0.019 & 0.000 & 0.001 & 0.000 & 0.022 & 0.008 & 0.000 & 0.000 & 0.000 \\
$\mathrm{~A}_{7}$ & 0.011 & 0.010 & 0.004 & 0.041 & 0.022 & 0.015 & 0.020 & 0.001 & 0.001 \\
$\mathrm{~A}_{8}$ & 0.011 & 0.006 & 0.000 & 0.027 & 0.011 & 0.015 & 0.020 & 0.004 & 0.000 \\
$\mathrm{~A}_{9}$ & 0.018 & 0.003 & 0.005 & 0.041 & 0.022 & 0.023 & 0.013 & 0.001 & 0.000 \\
\hline Reference points & 0.055 & 0.050 & 0.056 & 0.068 & 0.054 & 0.038 & 0.033 & 0.016 & 0.003 \\
\hline
\end{tabular}


Table 10. Ranking of alternatives with Reference Point Approach of MOORA

\begin{tabular}{cll}
\hline Alternatives & Brands & Max \\
\hline $\mathrm{A}_{1}$ & Mercedes C 200d & 0.014 \\
$\mathrm{~A}_{2}$ & Audi A4 2.0 TDI & 0.018 \\
$\mathrm{~A}_{6}$ & BMW 320 d & 0.022 \\
$\mathrm{~A}_{3}$ & Volkswagen Passat 2.0 TDI & 0.027 \\
$\mathrm{~A}_{5}$ & Opel Insignia 2.0 CDTI & 0.027 \\
$\mathrm{~A}_{8}$ & Toyota Avensis 2.0 D-3D & 0.027 \\
$\mathrm{~A}_{4}$ & Volvo S60 2.0 TDI & 0.033 \\
$\mathrm{~A}_{7}$ & Ford Mondeo 2.0 TDCI & 0.041 \\
$\mathrm{~A}_{9}$ & Peugeot 508 2.0 & 0.041 \\
\hline
\end{tabular}

In Full Multiplicative Form of MOORA, multiplicative ranking index $U_{i}$ for each alternative are determined with Eq. (14) and these values are given at last column of Table 11. Then ranking of the alternatives are obtained by ranking $U_{i}$ values in descending order. This ranking obtained by Full Multiplicative Form of MOORA can be seen in Table 12.

Table 11. Full Multiplicative Form of MOORA

\begin{tabular}{|c|c|c|c|c|c|c|c|c|c|c|}
\hline Alternatives & $\mathrm{C}_{1}$ & $\mathrm{C}_{2}$ & $\mathrm{C}_{3}$ & $\mathrm{C}_{4}$ & $\mathrm{C}_{5}$ & $\mathrm{C}_{6}$ & $\mathrm{C}_{7}$ & $\mathrm{C}_{8}$ & $\mathrm{C}_{9}$ & $U_{i}$ \\
\hline $\mathrm{A}_{1}$ & 11.093 & 1.273 & 1.753 & 1.268 & 1.205 & 1.145 & 1.126 & 1.230 & 1.050 & 0.286 \\
\hline $\mathrm{A}_{2}$ & 11.244 & 1.268 & 1.749 & 1.268 & 1.174 & 1.124 & 1.126 & 1.247 & 1.050 & 0.274 \\
\hline $\mathrm{A}_{3}$ & 10.705 & 1.288 & 1.737 & 1.176 & 1.136 & 1.097 & 1.084 & 1.235 & 1.051 & 0.235 \\
\hline $\mathrm{A}_{4}$ & 10.618 & 1.278 & 1.692 & 1.176 & 1.084 & 1.124 & 1.108 & 1.247 & 1.051 & 0.235 \\
\hline $\mathrm{A}_{5}$ & 10.873 & 1.337 & 1.753 & 1.176 & 1.174 & 1.124 & 1.084 & 1.241 & 1.054 & 0.239 \\
\hline $\mathrm{A}_{6}$ & 11.268 & 1.263 & 1.753 & 1.268 & 1.136 & 1.124 & 1.126 & 1.247 & 1.050 & 0.267 \\
\hline $\mathrm{A}_{7}$ & 10.994 & 1.302 & 1.737 & 1.108 & 1.136 & 1.097 & 1.052 & 1.244 & 1.052 & 0.208 \\
\hline $\mathrm{A}_{8}$ & 11.025 & 1.288 & 1.756 & 1.176 & 1.174 & 1.097 & 1.052 & 1.232 & 1.051 & 0.231 \\
\hline $\mathrm{A}_{9}$ & 11.222 & 1.273 & 1.728 & 1.108 & 1.136 & 1.060 & 1.084 & 1.244 & 1.051 & 0.207 \\
\hline
\end{tabular}

Table 12. Ranking of alternatives with Full Multiplicative Form of MOORA

\begin{tabular}{cll}
\hline Alternatives & Brands & $U_{i}$ \\
\hline $\mathrm{A}_{1}$ & Mercedes C 200d & 0.286 \\
$\mathrm{~A}_{2}$ & Audi A4 2.0 TDI & 0.274 \\
$\mathrm{~A}_{6}$ & BMW 320 d & 0.267 \\
$\mathrm{~A}_{5}$ & Opel Insignia 2.0 CDTI & 0.239 \\
$\mathrm{~A}_{3}$ & Volkswagen Passat 2.0 TDI & 0.235 \\
$\mathrm{~A}_{4}$ & Volvo S60 2.0 TDI & 0.235 \\
$\mathrm{~A}_{8}$ & Toyota Avensis 2.0 D-3D & 0.231 \\
$\mathrm{~A}_{7}$ & Ford Mondeo 2.0 TDCI & 0.208 \\
$\mathrm{~A}_{9}$ & Peugeot 508 2.0 & 0.207 \\
\hline
\end{tabular}

The final ranking of the alternatives are determined with MULTI-MOORA method. By using dominance theory one final ranking is obtained from three ranks of Ratio System, Reference Point Approach and Full Multiplicative Form. This final ranking is given in Table 12. According to the result of MULTI-MOORA, the final ranking of alternatives is obtained as $A_{1}>A_{2}>A_{6}>A_{5}>A_{3}>A_{4}>A_{8}>A_{7}>A_{9}$ and the best automobile alternative is A1 Mercedes C 200d
Table 13. Ranking of alternatives with MULTI- MOORA

\begin{tabular}{cccc}
\hline $\begin{array}{c}\text { Ratio System } \\
\text { of MOORA }\end{array}$ & $\begin{array}{c}\text { Reference } \\
\text { Point } \\
\text { Approach of } \\
\text { MOORA }\end{array}$ & $\begin{array}{c}\text { Full } \\
\text { Multiplicative } \\
\text { Form of } \\
\text { MOORA }\end{array}$ & $\begin{array}{c}\text { MULTI- } \\
\text { MOORA }\end{array}$ \\
\hline $\mathrm{A}_{1}$ & $\mathrm{~A}_{1}$ & $\mathrm{~A}_{1}$ & $\mathrm{~A}_{1}$ \\
$\mathrm{~A}_{2}$ & $\mathrm{~A}_{2}$ & $\mathrm{~A}_{2}$ & $\mathrm{~A}_{2}$ \\
$\mathrm{~A}_{6}$ & $\mathrm{~A}_{6}$ & $\mathrm{~A}_{6}$ & $\mathrm{~A}_{6}$ \\
$\mathrm{~A}_{5}$ & $\mathrm{~A}_{3}$ & $\mathrm{~A}_{5}$ & $\mathrm{~A}_{5}$ \\
$\mathrm{~A}_{4}$ & $\mathrm{~A}_{5}$ & $\mathrm{~A}_{3}$ & $\mathrm{~A}_{3}$ \\
$\mathrm{~A}_{3}$ & $\mathrm{~A}_{8}$ & $\mathrm{~A}_{4}$ & $\mathrm{~A}_{4}$ \\
$\mathrm{~A}_{8}$ & $\mathrm{~A}_{4}$ & $\mathrm{~A}_{8}$ & $\mathrm{~A}_{8}$ \\
$\mathrm{~A}_{7}$ & $\mathrm{~A}_{7}$ & $\mathrm{~A}_{7}$ & $\mathrm{~A}_{7}$ \\
$\mathrm{~A}_{9}$ & $\mathrm{~A}_{9}$ & $\mathrm{~A}_{9}$ & $\mathrm{~A}_{9}$ \\
\hline
\end{tabular}

\section{CONCLUSION}

In this paper, a combined approach based on MACBETH and MULTI-MOORA methods is proposed for the first time and its applicability is illustrated with an automobile selection problem of a marble company. Decision criteria are determined as price, fuel consumption, safety, brand image, after sales service, comfort, design, engine power and $\mathrm{CO}_{2}$ emissions. The weights of these criteria are determined with MACBETH 
method. Then the final ranking of the automobile alternatives is obtained with MULTI-MOORA method as $A_{1}>A_{2}>A_{6}>A_{5}>A_{3}>A_{4}>A_{8}>A_{7}>A_{9}$. As the best alternative is $A_{1}$, it is advised to the marble company to purchase Mercedes C 200d for the general manager. They found the results satisfactory and decided to purchase Mercedes C 200d.

In this paper, combined approach is based on MACBETH and MULTI-MOORA methods. These two MCDM methods are preferred because of their advantages over others. MACBETH has advantage because it only requires qualitative judgements to weight the criteria and to score the alternatives. Also, the support of MMACBETH software improves the usefulness of this method in solving complex decision-making problems [20]. On the other hand, this software provides a consistency checking and if the judgements are found inconsistent, it suggests possible alterations to make them consistent.

\section{References}

[1]. Güngör, İ., İşler D. B. (2004). Analitik Hiyerarşi Yaklaşimi İle Otomobil Seçimi, ZKÜ Sosyal Bilimler Dergisi, 1(2), 2133.

[2]. Terzi, Ü., Hacaloğlu, S.E., Aladağ, Z. (2006). Otomobil Satın Alama Problem için Bir Karar Destek Modeli, Ístanbul Ticaret Üniversitesi Fen Bilimleri Dergisi, 5(10), 43-49.

[3]. Soba, M. (2012). PROMETHEE Yöntemi Kullanarak En Uygun Panelvan Otomobil Seçimi ve Bir Uygulama, Journal of Yasar University, 28(7), 4708 - 4721.

[4]. Sakthivel, G. Ilangkumaran, M. Nagarajan, G. Raja, A. Ragunadhan P.M., Prakash, J. (2013.) A Hybrid MCDM Approach for Evaluating an Automobile Purchase Model, International Journal of Information and Decision Sciences, 5(1), 50-85.

[5]. Yavaș, M., Ersöz, T., Kabak, M. (2014). Otomobil Seçimine Çok Kriterli Yaklaşım Önerisi, Işletme ve İktisat Çalışmaları Dergisi, 2(4), 110-118.

[6]. Burgazoğlu, H, (2015). MACBETH, B.F. Yıldırım, E. Önder (Ed.), Çok Kriterli Karar Verme Yöntemleri, Bursa: Dora Yayınları.

[7]. Bana e Costa C.A., Chagas M. P. (2004). A Career Choice Problem: An Example of How to Use MACBETH to Build a Quantitative Value Model Based on Qualitative Value Judgments, European Journal of Operational Research, 153, 323-331.

[8]. Karande P., Chakraborty, S. (2014). A Facility Layout Selection Model Using MACBETH Method, Proceedings of the 2014 International Conference on Industrial Engineering and Operations Management, January 7 - 9, Bali, Indonesia.

[9]. Bana e Costa C.A., Ensslin, L., Correa E.C., Vansnick, J.C. (1999). Decision Support Systems in Action: Integrated Application in a Multicriteria Decision Aid Process, European Journal of Operational Research, 113, 315-335.

[10]. Bana e Costa C.A, Nunes da Silva, F., Vansnick, J.C. (2001). Conflict Dissolution in the Public Sector: A case-study, European Journal of Operational Research, 130, 388-401.

[11]. Bana e Costa, C.A. (2001). The Use of Multi-Criteria Decision Analysis to Support the Search for Less Conflicting Policy Options in a Multi-Actor Context: Case Study, Journal of Multi-Criteria Decision Analysis, 10, 111-125.

[12]. Bana e Costa C.A., Oliveira R.C. (2002). Assigning Priorities for Maintenance, Repair and Refurbishment in Managing a Municipal Housing Stock, European Journal of Operational Research, 138, 380-391.
MULTI-MOORA method combines the results of three MOORA approach namely Ratio System, Reference Point Method and Full Multiplicative Form. For this reason it gives guarantee for robustness [41]. This is the advantage of MULTI-MOORA over other MCDM methods. Also, Full Multiplicative Form of MOORA does not need the use of normalization. This reduces the amount of calculations required and saves time.

In future studies, proposed combined approach can be used to solve different MCDM problems of the companies. And the weights of the criteria can be determined with AHP (Analytic Hierarch Process) method instead of MACBETH. Also other MCDM methods can be used for ranking the alternatives and the obtained results can be compared.

13]. Bana e Costa C.A, Costa-Lobo M.L., Ramos, I.A., Vansnic, J.C. (2002a). Multicriteria Approach for Strategic Town Planning. In D. Bouyssou et al. (Ed.), Aiding Decisions with Multiple Criteria, Kluwer Academic Publishers.

[14]. Bana e Costa, C.A., Barroso, L.A., Soares, J.O. (2002b). Qualitative Modelling of Credit Scoring: A Case Study in Banking, European Research Studies, 5 (1-2), 37-51.

[15]. Bana e Costa C.A., Correa, E.C., De Corte, J.-M.,Vansnic , J.C. (2002c). Facilitating Bid Evaluation in Public Call for Tenders: A Socio-Technical Approach, Omega, 30, 227 242.

[16]. Roubens, M., Rusinowska, A., De Swart, H. (2006). Using MACBETH to Determine Utilities of Governments to Parties in Coalition Formation, European Journal of Operational Research, 172, 588-603.

[17]. Cliville V., Berrah L., Mauris, G. (2007). Quantitative Expression and Aggregation of Performance Measurements Based on the MACBETH Multi-Criteria Method, International Journal of Production Economics, 105, 171189.

[18]. Montignac, F., Noirot, I., Chaudourne, S. (2009). MultiCriteria Evaluation of On-Board Hydrogen Storage Technologies Using the MACBETH Approach, International Journal hydrogen energy, 34, 4561 - 4568.

[19]. Fakhfakh, N., Verjus, H., Pourraz, F., Moreaux, P. (2011). Measuring the Satisfaction Degree of Quality Attributes Requirements for Services Orchestrations, Proceedings of 4th International Conference on Communication Theory, Reliability, and Quality of Service, Hungary, pp. 89-94.

[20]. Karande, P., Chakraborty, S. (2013). Using MACBETH Method for Supplier Selection in Manufacturing Environment, International Journal of Industrial Engineering Computations, 4, 259-272.

[21]. Rodrigues, T.C. (2014). The MACBETH Approach to Health Value Measurement: Building a Population Health Index in Group Processes, Procedia Technology, 16, 1361 - 1366.

[22]. Brauers, W.K.M., Zavadskas, E.K. (2006). The MOORA Method and Its Application to Privatization in a Transition Economy. Control and Cybernetics, 35(2), 445-469.

[23]. Brauers, W.K.M., Zavadskas, E.K., Turskis, Z. Vilutiene, T. (2008). Multi-Objective Contractor's Ranking by Applying the MOORA Method. Journal of Business Economics and Management, 9(4), 245-255.

[24]. Brauers, W.K.M., Zavadskas, E.K., Peldschus, F., Turskis, Z. (2008). Multi-Objective Decision Making for Road Design, Transport, 23(3), 183-193. 
[25]. Kalibatas, D., Turskis Z. (2008). Multicriteria Evaluation of Inner Climate by Using MOORA Method. Information Technology and Control, 37(1), 79-83.

[26]. Brauers, W.K.M., Ginevičius, R. (2009). Robustness in Regional Development Studies: The Case of Lithuania. Journal of Business Economics and Management, 10(2), 121-140.

[27]. Brauers, W.K.M., Ginevičius, R., Podvezko, V. (2010). Regional Development in Lithuania Considering Multiple Objectives by The MOORA Method. Technological and Economic Development of Economy, 16(4), 613-640.

[28]. Brauers, W.K.M., Zavadskas, E.K. (2010). Project Management by Multimoora as an Instrument for Transition Economies. Technological and Economic Development of Economy, 16(1), 5-24.

[29]. Gadakh, V. S. (2011). Application of MOORA Method for Parametric Optimization of Milling Process. International Journal of Applied Engineering Research, 1 (4), 743-758.

[30]. Archana, M., Sujatha, V. (2012). Application of Fuzzy MOORA and GRA in Multi Criterion Decision Making Problems, International Journal of Computer Applications, 53(9), 46-50.

[31]. Karaca, T. (2011). Proje Yönetiminde Çok Kriterli Karar Verme Teknikleri Kullanarak Kritik Yolun Bulunmasi. (Yayımlanmamıs yüksek lisans tezi). Gazi Üniversitesi/ Fen Bilimleri Enstitüsü, Ankara.

[32]. Önay, O., Cetin, E. (2012). Turistik Yerlerin Popülaritesinin Belirlenmesi: İstanbul Örneği. Yönetim: İstanbul Üniversitesi İsletme Iktisadı Enstitüsü Dergisi, 23(72), 90-109.

[33]. Dey, B., Bairagi, B., Sarkar, B., Sanyal, S. (2012). A Moora Based Fuzzy Multi Criteria Decision Making Approach for Supply Chain Strategy Selection. International Journal of Industrial Engineering Computations, 3, 649-662.

[34]. Mandal, U. K.ve Sarkar, B. (2012). Selection of Best Intelligent Manufacturing System Under Fuzzy MOORA Conflicting MCDM Environment. International Journal of Engineering Technology and Advanced Engineering, 2(9), 301-310.

[35]. Balezantis, A., Balezantis, T., Brauers, W.K.M. (2012). Multimoora-FG: A Multi-Objective Decision Making Method for Linguistic Reasoning with an Application to Personnel Selection. Informatica, 23(2), 173-190.

[36]. Tepe, S., Görener, A. (2014). Analitik Hiyerarşi Süreci ve MOORA Yöntemlerinin Personel Seçiminde Uygulanması. İstanbul Ticaret Üniversitesi Fen Bilimleri Dergisi, 13(25), $1-14$

[37]. Görener, A., Dinçer, H., Hacioğlu, Ü. (2013). Application of Multi-Objective Optimization on the Basis of Ratio Analysis (MOORA) Method for Bank Branch Location Selection. International Journal of Finance \& Banking Studies, 2(2), 41-52.

[38]. Yıldırım, B.F., Önay, O. (2013). Bulut Teknolojisi Firmalarının Bulanık AHP- MOORA Yöntemi Kullanılarak Suralanması, İ.Ü.İsletme Fakültesi, İşletme İktisadı Enstitüsü Yönetim Dergisi, 24(75), 59-81.

[39]. Obayiuwana, E. Falowo, O. (2015) A Multimoora Approach to Access Network Selection Process in Heterogeneous Wireless Networks, AFRICON 2015, 14-17 September, Addis Ababa, IEEE, pp. 1-5, doi.10.1109/AFRCON. 2015.7331973

[40]. Brauers W. K. M., Zavadskas E.K. (2011). Multimoora Optimization Used to Decide on a Bank Loan to Buy Property, Technological and Economic Development of Economy, 17(1), 174-188.

[41]. Brauers, W.K.M., Ginevičius R. (2010). The Economy of The Belgian Regions Tested with Multimoora, Journal of Business Economics and Management, 11:2, 173-209.

[42]. Brauers, W. K. M., Baležentis A., Baležentis, T. (2011).Multimoora for the EU Member States Updated with Fuzzy Number Theory, Technological and Economic Development of Economy, 17:2, 259-290.
[43]. Baležentis A., Baležentis, T., Brauers W. K. M., (2012) MULTIMOORA-FG: A Multi-Objective Decision Making Method for Linguistic Reasoning with an Application to Personnel Selection, Informatica, 23(2), 173-190.

[44]. Brauers W. K. M., Zavadskas E.K. (2012). Robustness of MULTIMOORA: A Method for Multi-Objective Optimization, Informatica, 23(1), 1-25.

[45]. Datta S., Sahu, N., Mahapatra, S. (2013). Robot Selection Based on Grey-MULTIMOORA Approach, Grey Systems: Theory and Application, 3(2), 201 - 232.

[46]. Baležentis T., Baležentis, A. (2014). A Survey on Development and Applications of the Multi-criteria Decision Making Method MULTIMOORA, Journal Of Multi-Criteria Decision Analysis, 21, 209-222.

[47]. Aksoy, E. (2015). AHP Temelli MULTIMOORA ve COPRAS Yöntemi ile Türkiye Kömür İşletmeleri'nin Performans Değerlendirmesi, Hacettepe Üniversitesi İktisadi ve İdari Bilimler Fakültesi Dergisi, 33(4), 1-28.

[48]. http://www.mercedes-benz.com.tr/content/turkey/mpc/mpc turkey_website/tr/home_mpc/passengercars/home/new_cars/ models/c-class/c205/advice_sales/brosur.html [17.01.2016]

[49]. http://www.audi.com.tr/tr/brand/tr/models/a4/a4_sedan/tekn k_veriler/boyutlar.html\#source=http://www.audi.com.tr/tr/br and/tr/models/a4/a4_sedan/teknik_veriler/teknik_detay.html \&container=page [17.01.2016]

[50]. http://binekarac.vw.com.tr/pdf/passat.pdf [17.01.2016]

[51]. http://www.volvocars.com/tr/modeller/new-models/s60/ ozellikler [17.01.2016]

[52]. http://www.opel.com.tr/content/dam/Opel/Europe/turkey/nsc website/tr/11_Brochure_Library/02_Specsheets/Insignia_M Y16.5_FINAL.pdf [17.01.2016]

[53]. http://www.bmw.com.tr/content/dam/bmw/marketTR/bmw com_tr/pdf/bmw_3_serisi_sedan_katalog_f30.pdf.asset.1457 705813418.pdf [17.01.2016]

[54]. https://apps.ford.com.tr/ebrochure/brochurefiles/mondeo.pdf [17.01.2016]

[55]. https://www.toyota.com.tr/new-cars/avensis/index.json\#/ publish/compare_engines/selection=2WW-20D1-1436M [17.01.2016]

[56]. http://www.peugeot.com.tr/media/deliacms/media//74/7412 88db21.pdf [17.01.2016]

[57]. http://www.euroncap.com/tr [18.01.2016] 